\section{Radiopacity Evaluation of Gutta- Percha Points in Thinner Samples than the ANSI/ADA Recommendation}

\author{
Bruna Lucian Petry ${ }^{1}$, Augusto Bodanezi², Flávia Emi Razera Baldassoํ․ \\ Débora Delai ${ }^{1}$, Naiara Leites Larentis ${ }^{3}$, Vania Regina Camargo Fontanella4, \\ Patrícia Maria Poli Kopper ${ }^{1}$
}

\begin{abstract}
The aim of this study was to evaluate the radiopacity of different gutta-percha points (Endo Points ${ }^{\circledR}$, Dentsply ${ }^{\circledR}$, Tanari $^{\circledR}$, Meta $^{\circledR}$, Roeko $^{\circledR}$ and Odous ${ }^{\circledR}$ ) in samples of 1 mm thick as established by ANSI/ADA Specification \#57 and ISO 6876/2001, in comparison with thinner samples. Twelve test specimens for each material, four for each thickness $(0.3$, 0.6 , and $1 \mathrm{~mm}$ and diameter of $8 \mathrm{~mm}$ ), were laminated and compressed between two polished glass plates until the desirable thickness. Digital radiographs were obtained along with a graduated aluminum stepwedge varying from 1 to $10 \mathrm{~mm}$ in thickness. The $\mathrm{X}$-ray unit was set at $70 \mathrm{kVp}, 10 \mathrm{~mA}$ and $0.4 \mathrm{~s}$ exposure time, at a focal distance of $36 \mathrm{~cm}$. One calibrated observer quantified the average values of pixels with Adobe Photoshop ${ }^{\circledR}$ software. Data were analyzed using ANOVA and Tukey tests, at 5\% significance level. At 0.6 and $1 \mathrm{~mm}$ thickness, all the tested materials showed radiopacity higher than 3 $\mathrm{mm}$ of aluminum (reference value). At $0.3 \mathrm{~mm}$ thickness, Odous and Tanari presented significantly less radiopacity than the reference, and the other materials showed similar radiopacity to the reference. The study concluded that the materials demonstrated different radiopacities and all had values above the minimum recommended by ANSI/ ADA specification \#57, being Odous and Tanari less radiopaque than the reference value in thinner samples $(0.3 \mathrm{~mm})$.
\end{abstract}

'Department of Conservative Dentistry, Dental School, UFRGS Universidade Federal do Rio Grande do Sul, Porto Alegre, RS, Brazil ${ }^{2}$ Department of Conservative Dentistry, UFSC - Universidade Federal de Santa Catarina, Florianópolis, SC, Brazil ${ }^{3}$ Department of Radiology, ULBRA - Universidade Luterana do Brasil, Torres, RS, Brazil ${ }^{4}$ Surgery and Orthopaedics Department, Dental School, UFRGS Universidade Federal do Rio Grande do Sul, Porto Alegre, RS, Brazil

Correspondence: Vania Regina Camargo Fontanella, Rua Ramiro Barcelos, 2492, 90035-004 Porto Alegre, RS, Brasil. Tel: +55-51-98116-6838. e-mail: vaniafontanella@terra.com.br

Key Words: endodontics, guttapercha, radiology, radiopacity.

\section{Introduction}

International standards require that gutta-percha points be sufficiently radiopaque to permit evaluation of the density of the root canal filling and to be distinguished from the tooth structures $(1,2)$. The dependence of dental diagnosis on radiographs makes it necessary for all materials used in the oral cavity to be radiopaque. So, in all commercial brands of gutta-percha points, different radiopacifying agents are added in several concentrations (3).

The ANSI/ADA Specification \#57 for endodontic sealing materials establishes the minimal value of radiopacity, stating that $1 \mathrm{~mm}$ thick of gutta-percha must have a radiopacity not less than the equivalent to $3 \mathrm{~mm}$ of aluminum (1). However, the specification does not state the maximal radiopacity value, giving autonomy to manufacturers to choose the radiopacifying agents and their concentrations. Due to root canal filling aesthetic appreciation, gutta-percha points of different commercial brands have been produced with two to three times more radiopacity than the minimal required (4-5).

Considering that, during the endodontic therapy, after biomechanical preparation, the diameter of the root canal at the apical region is frequently less than 1 $\mathrm{mm}$ (6), the investigation of gutta-percha radiopacity in a thickness smaller than $1 \mathrm{~mm}$ is critical. According to ANSI/ADA, the minimal radiopacity value for gutta-percha must be determined at $1 \mathrm{~mm}$ thinness in vitro samples and do not consider the superposing of anatomical structures and different thick of filling along the root canal. In a recent investigation, a new in vitro method was proposed to evaluate radiopacity of endodontic materials using a tissue simulator to approximate radiopacity evaluation to the clinical reality. It was observed that the superimposition of anatomical structures increases the filling material radiopacity (7). So, since most root canal fillings are distinguished from anatomical structures during radiographic analysis, even in smaller diameters than $1 \mathrm{~mm}$, is important to investigate the gutta-percha radiopacity in thinner samples than the recommendation.

Currently, there are no studies in the literature concerning the radiopacity of gutta-percha brands at thicknesses lower than that determined by the ANSI/ ADA specification \#57 (1) and that have discussed its implications in clinical aspects. Therefore, this study aimed to evaluate the radiopacity of different gutta-percha points (Endo Points ${ }^{\circledR}$, Dentsply ${ }^{\circledR}$, Tanari ${ }^{\circledR}$, Meta ${ }^{\circledR}$, Roeko ${ }^{\circledR}$ and Odous $^{\circledR}$ ) using digital radiography and the aluminum stepwedge method, in samples of $1 \mathrm{~mm}$ thick as established 
by ANSI/ADA Specification \#57 (1) and IS0 6876/2001 (2), in comparison with thinner samples.

\section{Material and Methods}

\section{Sample Preparation}

Six gutta-percha brands were evaluated in this study: Endo Points ${ }^{\circledR}$, Dentsply ${ }^{\circledR}$, Tanari ${ }^{\circledR}$, Meta ${ }^{\circledR}$, Roeko ${ }^{\circledR}$, and Odous ${ }^{\circledR}$ (Table 1). Twelve test specimens with thicknesses of $0.3,0.6$ and $1( \pm 0.02) \mathrm{mm}$ and diameter of $8( \pm 0.02)$ $\mathrm{mm}$ were made from each material $(n=4)$. For specimen confection, three gutta-percha points, placed on a glass plate, were laminated on the flame of a lamp in order to obtain a homogeneous malleable mass that was compressed manually between two smooth glass plates. The plastification and compression procedures were repeated until obtaining gutta-percha thicknesses of $0.3 \pm 0.02 \mathrm{~mm}$, $0.6 \pm 0.02 \mathrm{~mm}$ or $1.00 \pm 0.02 \mathrm{~mm}$. The specimens' thicknesses were confirmed at three different points of the sample using a digital caliper (ME 727, Starrett Co., Athol, MA, USA). After, the edges of the circular gutta-percha discs were cut out circumferentially, resulting in standardized specimens with eight millimeters in diameter.

\section{Radiographic Procedures}

The specimens were positioned over an occlusal radiographic sensor (Digora Soredex, Digora Soredex, Tuusula, Finland) along with an aluminum stepwedge (1100 alloy) with variable thickness (from 1 to $10 \mathrm{~mm}$ in increments of $1 \mathrm{~mm}$ ). Four sets of each material, containing three specimens of different thickness, were positioned and radiographed using a radiographic unit (Timex 70C, Gnatus, Ribeirão Preto, SP, Brazil) operating at 70 kVp, 10 $\mathrm{mA}, 0.4 \mathrm{~s}$ exposure time and a focal distance of $36 \mathrm{~cm}$ (Fig. 1). Specimens with radiographic image voids or defects were replaced.

\section{Radiopacity Assessment}

The generated images (TIFF format) were encoded and analyzed by one blinded and calibrated examiner $($ ICC $=1)$, as

Table 1. Gutta-percha brands tested

\begin{tabular}{lc}
\hline Gutta-percha Brand & Manufacturer \\
\hline Dentsply & Dentsply, Petrópolis, RJ, Brazil. \\
Endo Points & Endopoints, Manacapuru, AM, Brazil. \\
Meta & GN Injecta, Diadema, SP, Brazil. \\
Odous & Odous, Belo Horizonte, MG, Brazil. \\
Roeko & Coltène Whaledent, Vigodent, \\
Tanari & Rio de Janeiro, RJ, Brazil \\
\hline
\end{tabular}

described by Malka et al. (7). Briefly, the examiner evaluated the images at a $50 \mathrm{~cm}$ distance from a 24-inch liquid crystal display monitor under dimmed light. The digital images were analyzed with Adobe Photoshop ${ }^{\circledR}$ software v. 10.0 (Adobe Systems, San Jose, CA, USA). A standard-size circle (400 pixels) was drawn in the center of the disc and another circle was drawn in the sixth step of the aluminum stepwedge, equivalent to $3 \mathrm{~mm}$ of aluminum (reference value). The average and standard deviation of the gray scale pixel values in each area selected were measured using the histogram tool and were recorded.

Then, the mean radiopacity values were calculated for each group and used for the statistical comparisons.

\section{Statistical Analysis}

Data were submitted to statistical analysis at SPSS ${ }^{\circledR}$ software, v. 10.0 (SPSS Inc., Chicago, IL, USA ), using oneway analysis of variance (ANOVA), followed by Tukey test, for comparing the radiopacity among thicknesses, materials and the reference value. The correlation between the specimens' thickness and the greyscale pixel values was determined by Pearson test $(\alpha=0.05 \%)$.

\section{Results}

Table 2 summarizes data for radiopacity comparison. At 0.6 and $1 \mathrm{~mm}$ thickness, all the tested materials showed radiopacity higher than $3 \mathrm{~mm}$ of aluminum (reference value). At $0.3 \mathrm{~mm}$ thickness, Odous and Tanari presented significantly less radiopacity than the reference and the other materials showed similar radiopacity to the reference.

At $0.3 \mathrm{~mm}$ thickness, Tanari ${ }^{\circledR}$ and Odous ${ }^{\circledR}$ showed lower radiopacity than Dentsply ${ }^{\circledR}$, Endo Points ${ }^{\circledR}$ and Meta ${ }^{\circledR}$ $(p<0.05)$. At 0.6 mm, Dentsply ${ }^{\circledR}$, Endo Points ${ }^{\circledR}$, Meta ${ }^{\circledR}$, and Tanari ${ }^{\circledR}$ showed higher radiopacity than Odous $^{\circledR}$ and Roeko $^{\circledR}(p<0.05)$. At $1 \mathrm{~mm}$ thickness, Tanari ${ }^{\circledR}$ and Meta ${ }^{\circledR}$ showed higher radiopacity than Dentsply ${ }^{\circledR}$, Odous $^{\circledR}$ and Roeko $^{\circledR}(p<0.05)$.

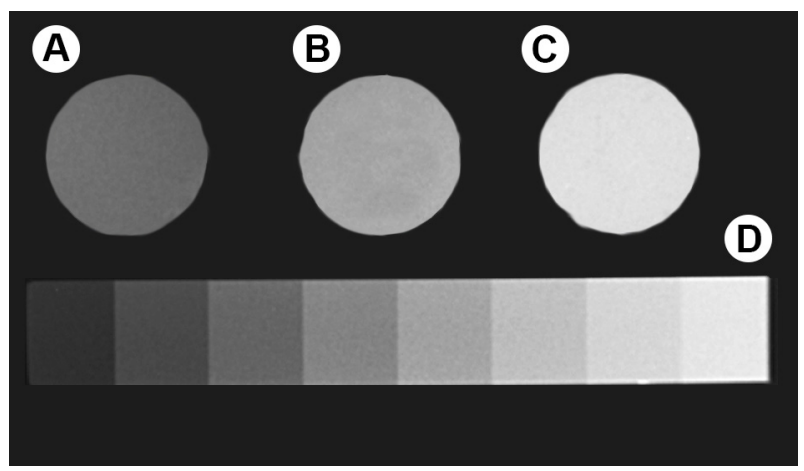

Figure 1. Radiographic image of the specimens in $0.3 \mathrm{~mm}$ thickness (A), $0.6 \mathrm{~mm}(\mathrm{~B}), 1 \mathrm{~mm}(\mathrm{C})$, next to the aluminum scale (D). 
Pearson test showed a positive correlation between gutta-percha thickness and greyscale pixel values $(r=+0.4943)$.

\section{Discussion}

This study evaluated the radiopacity of different gutta-percha brands using a digital radiographic method. Although revised in 2012, ANSI/ADA \#57 specification (1) does not provide parameters for the use of more sensitive digital receptors and software for measuring radiopacity as pixel intensity, which is the reality of modern radiology. However, the use of the aluminum scale, $X$-rayed along with the specimen (8-14), is intended to expose both objects to the same parameters.

Baksi et al. (15) were the first authors to compare the radiopacity of sealers using digital radiography. Since then, digital technology has been used in several other studies $(5,7,11-20)$ to optimize the quantitative analysis of radiographic images, thereby bringing improvements in the diagnosis and treatment decisions (15), while reducing the exposure and the working time (19).

Several studies have evaluated the radiopacity of guttapercha using an aluminum stepwedge as a comparison $\vec{z}$ standard $(3,4)$, since the filling materials must have a \pm minimum degree of radiopacity to be distinguished from soft and mineralized tissues during radiographic analysis $(1,15)$. For root canal filling materials, it was established that the minimal radiopacity value for $1 \mathrm{~mm}$ thick of guttapercha must be equal or higher than that generated by 3 $\mathrm{mm}$ of aluminum $(1,2)$. Also, the ANSI/ADA Specification \#57 (1) and ISO 6876/2001 (2) establishes that the filling materials radiopacity must be measured in specimens with 1 or $2 \mathrm{~mm}$ thick.

The evaluation of gutta-percha radiopacity in a

Table 2. Mean values and standard deviations of pixels observed for each gutta-percha brand in $0.3,0.6$ and $1 \mathrm{~mm}$ thickness and for $3 \mathrm{~mm}$ thickness of the aluminum stepwedge

\begin{tabular}{|c|c|c|c|c|}
\hline \multirow{3}{*}{$\begin{array}{l}\text { Gutta-percha } \\
\text { brand }\end{array}$} & \multicolumn{4}{|c|}{ Thickness (mm) } \\
\hline & \multicolumn{3}{|c|}{ Gutta-percha } & \multirow{2}{*}{$\begin{array}{c}\text { Aluminum } \\
3.0\end{array}$} \\
\hline & 0.3 & 0.6 & 1.0 & \\
\hline Dentsply & $113.12 \pm 7.96^{\mathrm{aA}}$ & $175.54 \pm 9.68^{\mathrm{bA}}$ & $208.94 \pm 3.07^{\mathrm{bB}}$ & $105.88 \pm 2.36^{\mathrm{a}}$ \\
\hline Endo Points & $120.71 \pm 5.50^{\mathrm{aA}}$ & $178.91 \pm 8.51^{\mathrm{bA}}$ & $227.02 \pm 1.81^{\mathrm{bAB}}$ & $109.52 \pm 3.63^{\mathrm{a}}$ \\
\hline Meta & $126.30 \pm 16.38^{\mathrm{aA}}$ & $175.15 \pm 12.62^{\mathrm{bA}}$ & $229.66 \pm 6.19^{\mathrm{bA}}$ & $124.85 \pm 11.07^{\mathrm{a}}$ \\
\hline Odous & $91.45 \pm 4.73^{\mathrm{bB}}$ & $154.92 \pm 6.02^{\mathrm{bB}}$ & $213.97 \pm 4.35^{\mathrm{bB}}$ & $107.18 \pm 6.47^{a}$ \\
\hline Roeko & $100.15 \pm 7.57^{\mathrm{aAB}}$ & $143.40 \pm 3.95^{\mathrm{bB}}$ & $209.24 \pm 5.05^{\text {bB }}$ & $108.01 \pm 3.83^{\mathrm{a}}$ \\
\hline Tanari & $87.97 \pm 5.85^{\mathrm{bB}}$ & $163.55 \pm 9.13^{\mathrm{bA}}$ & $223.94 \pm 4.65^{\mathrm{bA}}$ & $102.04 \pm 2.18^{a}$ \\
\hline
\end{tabular}

Different lowercase letters represent a significant difference between gutta-percha and aluminum $(\mathrm{P}<0.05)$. Different capital letters represent a significant difference between the gutta-percha brands with the same thickness ( $p<0.05$ ). reference value. thickness smaller than $1 \mathrm{~mm}$ can be justified by the fact that root canal diameters in the apical portions frequently is less than $1 \mathrm{~mm}$ thicknesses after chemo-mechanical procedures completion (6). For curved root canals, the last instrument used at working length is usually 0.25 or 0.30 diameter. Consequently, the gutta-percha point used for filling has the same diameter at its tip, that is, less than $1 \mathrm{~mm}$ (6). However, even being thinner, most root canal fillings are supposed to be distinguished from adjacent anatomical structures during radiographic analysis. The results of this research support this statement, since most trademarks tested, except Odous ${ }^{\circledR}$ and Tanari ${ }^{\circledR}$ at $0.3 \mathrm{~mm}$, showed values of radiopacity greater or equal to the

At $1 \mathrm{~mm}$ thickness, the radiopacity level detected for all brands were adequate, according to the ANSI/ADA Specification \#57 (1) and did not differ from those found in other studies $(3,5,12)$.

At $0.6 \mathrm{~mm}$ thickness, the six gutta-percha brands evaluated reached the minimum radiopacity recommended. This result suggests that possibly the root canal fillings with equivalent or larger diameter than $0.6 \mathrm{~mm}$, regardless of the brand of gutta-percha employed, are suitably distinguished from adjacent structures during radiographic analysis.

However, at $0.3 \mathrm{~mm}$ thickness, Odous ${ }^{\circledR}$ and Tanari ${ }^{\circledR}$ presented lower radiopacity than the minimum recommended by ANSI/ADA Specification \#57 (1). This fact could be considered useful, once the radiopacity excess could hide flaws present in the filling material, as observed by Gurgel-Filho et al. (20) for Tanari ${ }^{\circledR}$ group. The absence of barium sulfate in the gutta-percha cones of these trademarks may be related to the lower radiopacity $(20,21)$. Barium is a chemical element with atomic number greater than Zinc and, thus, barium sulfate (BaSO4) absorbs X-rays faster than zinc oxide, providing high radiopacity to the material (22).

According to Maniglia-Ferreira et al. (21), Endo Points also has no barium sulfate in its composition. However, as in this study, the authors observed that the guttapercha radiopacity was above the minimum recommended value for all investigated thicknesses, showing that the absence of this component did not compromise its radiopacity. Tanomaru et al. (23) suggested that this fact probably is due to the addition of other radiopacifying agents not reported by the manufacturer, such as 
bismuth subcarbonate and bismuth oxide, commonly present in the composition of some sealers.

The Pearson correlation test demonstrated that the average gray level increased as the filling material became thicker. This finding is important since it is known that the root canals become tapered after cleaning and shaping (24), occurring different radiopacity levels along the root canal filling. However, the perception of these differences in radiographic images by the human eye and its influence on the diagnostic skills are still unknown. Furthermore, besides the radiopacity generated by the gutta-percha points, the radiopacity produced by the sealer should be considered, especially in the apical part of the canal, wherein the amount of gutta-percha is lower $(15,25)$.

Some investigations revealed radiographic detection of defects in the apical third of fillings was easier than in the medium and cervical thirds $(16,24)$. It is important to point out that, from a clinical perspective, as gutta-percha is associated with sealer and with the superposition of anatomic structures that influence its radiopacity, points with less radiopacity could facilitate failures identification, mainly in thicker portions of the root canal (medium and cervical thirds). Therefore, the clinical advantage of gutta-percha points with higher radiopacity than the recommended is questionable, since it can hide root canal filling defects.

Due to the importance of the filling material radiopacity in defects identification (16), it is suggested to discuss the possibility of including, in the ISO 6876/2001 standards (2) and the ANSI/ADA specification \#57 (1) parameters for gutta-percha radiopacity evaluation in smaller thickness specimens. Besides, it would be interesting to adapt the standards considering the digital systems (17) and to standardize methods to address the radiopacity generated by the association of gutta-percha and sealers, to approach the relationship between the laboratory findings with those produced during clinical practice. So, further studies are suggested to evaluate the behavior of the gutta-percha radiopacity associated with endodontic sealers.

Considering the limitations of this in vitro laboratory study, it can be concluded that all gutta-percha brands evaluated presented appropriate radiopacity, above the minimum recommended by the $\mathrm{ISO}^{\mathrm{S}}$, being $\mathrm{Odous}^{\circledR}$ and Tanar ${ }^{\circledR}$ less radiopaque than the reference value in thinner samples $(0.3 \mathrm{~mm})$.

\section{Resumo}

0 objetivo deste estudo foi avaliar a radipacidade de diferentes pontas de guta-percha (Endo Points ${ }^{\circledR}$, Dentsply ${ }^{\circledR}$, Tanari ${ }^{\circledR}$, Meta ${ }^{\circledR}$, Roeko ${ }^{\circledR}$ e Odous $^{\circledR}$ ) em amostras de $1 \mathrm{~mm}$ de espessura, conforme estabelecido pela especificação \#57 da ANSI/ADA e pela ISO 6876/2001, em comparação com amostras de menor espessura. Doze amostras de cada material, quatro para cada espessura $(0,3,0,6$ e $1 \mathrm{~mm} ; 8 \mathrm{~mm}$ de diâmetro), foram confeccionadas por meio de laminação e compressão entre duas lâminas de vidro polidas, até a espessura desejada. Radiografias digitais foram obtidas juntamente com uma escala de alumínio graduada, com espessuras variando de 1 a $10 \mathrm{~mm}$. 0 aparelho de raios $X$ foi ajustado para $70 \mathrm{kVp}, 10 \mathrm{~mA}, 0,4 \mathrm{~s}$ de tempo de exposição, com distância focal de $36 \mathrm{~cm}$. Um observador calibrado quantificou a média dos valores de pixel no programa Adobe Photoshop ${ }^{\circledR}$. Os dados foram analisados utilizando os testes ANOVA e Tukey, com nivel de significância de 5\%. Nas espessuras de 0,6 e $1 \mathrm{~mm}$, todos os materiais testados apresentaram radiopacidade maior do que $3 \mathrm{~mm}$ de aluminio (valor de referência). $\mathrm{Na}$ espessura de $0,3 \mathrm{~mm}$, Odous e Tanari apresentaram radiopacidade significativamente menor que a referência, e as outras marcas mostraram radiopacidade semelhante à referência. Conclui-se que os materiais apresentaram diferentes radiopacidades e todos mostraram valores acima do mínimo recomendado pela especificação \#57 da ANSI/ADA, sendo Odous e Tanari menos radiopacos do que o valor de referência nas amostras mais finas $(0.3 \mathrm{~mm})$.

\section{References}

1. American National Standards Institute. American Dental Association. Specification (ANSI/ADA). Endodontic sealing materials. Chicago, 2000.

2. International Organization for Standardization. ISO 6876: dental root canal sealing materials. 2. ed. Geneva, Switzerland, 2001.

3. Katz A, Kaffe I, Littner M, Tagger M, Tamse A. Densitometric measurement of radiopacity of gutta-percha cones and root dentin. J Endod 1990;16:211-213.

4. Tanomaru-Filho M, Jorge EG, Guerreiro Tanomaru JM, Gonçalves M. Radiopacity evaluation of new root canal filling material by digitalization of images. J Endod 2007;33:249-251.

5. Carvalho-Júnior JR, Correr-Sobrinho $L$, Correr $A B$, Sinhoreti $M A$ Consani S, Sousa-Neto MD. Radiopacity of root filling materials using digital radiography. Int Endod J 2007;40:514-520.

6. Hoppe CB, Bottcher DE, Justo AM, Só MV, Grecca FS. Comparison of curved root canals preparation using reciprocating, continuous and an association of motions. Scanning 2016;11:1-7.

7. Malka VB, Hochscheidt GL, Larentis NL, Grecca FS, Fontanella VR, Kopper PM. A new in vitro method to evaluate radio-opacity of endodontic sealers. Dentomaxillofac Radiol 2015;44:1-5.

8. Lucas CPTP, Viapiana R, Bosso-Martelo R, Guerreiro-Tanomaru JM, Camilleri J, Tanomaru-Filho M. Physicochemical properties and dentin bond strength of a tricalcium silicate-based retrograde material. Braz Dent J 2017;28:51-56

9. Vazquez-Garcia F, Tanomaru-Filho M, Chávez-Andrade GM, BossoMartelo R, Basso-Bernardi MI, Guerreiro-Tanomaru JM. Effect of silver nanoparticles on physicochemical and antibacterial properties of calcium silicate cements. Braz Dent J 2016;27:508-514.

10. Segato RAB, Pucinelli CM, Ferreira DCA, Daldegan AR, Silva RS, NelsonFilho $P$, et al. Physicochemical properties of root canal filling materials for primary teeth. Braz Dent J 2016; 27:196-201.

11. Cañadas PS, Berástegui $E$, Gaton-Hernández $P$, Silva $L A B$, Leite GA, Silva RS. Physicochemical properties and interfacial adaptation of root canal sealers. Braz Dent J 2014;25:435-441.

12. Rasimick BJ, Shah RP, Musikant BL, Deutsch AS. Radiopacity of endodontic materials on film and a digital sensor. J Endod 2007;33:1098-1101.

13. Gu S, Rasimik BJ, Deutsch AS, Musikant BL. Radiopacity of dental materials using a digital X-ray system. Dent Mater 2005;22:765-770.

14. Akdeniz, BG, Soğur, E. An ex vivo comparison of conventional and digital radiography for perceived image quality of root fillings. Int Endod J 2005;38:397-401.

15. Baksi BG, Eyuboglu TF, Sen BH, Erdilek N. The effect of three different sealers on the radiopacity of root fillings in simulated canals. Oral Surg. Oral Med. Oral Pathol. Oral Radiol. Endod 2007;103:138-141.

16. Baksi BG, Sen BH, Eyuboglu TF. Differences in aluminum equivalent values of endodontic sealers: conventional versus digital radiography. J Endod 2008;34,1101-1104.

17. Dantas RV, Sarmento HR, Duarte RM, Meireles Monte Raso SS, de Andrade AK, Dos Anjos-Pontual ML. Radiopacity of restorative composites by conventional radiograph and digital images with 
different resolutions. Imaging Sci Dent 2013;43:145-151.

18. Tanalp J, Karapınar-Kazandağ M, Dölekoğlu S, Kayahan MB. Comparison of the radiopacities of different root-end filling and repair materials. Scientific World J [S.I.], 2013. Doi: 101155/2013/594950.

19. McDonnell $D$, Price C. An evaluation of the Sens-A-Ray digital dental imaging system. Dentomaxillofac Radiol 1993;22:121-126.

20. Gurgel-Filho ED, Andrade Feitosa JP, Teixeira FB, Monteiro de Paula $\mathrm{RC}$, Araújo Silva JB, Souza-Filho FJ. Chemical and X-ray analysis of five brands of dental gutta-percha cone. Int Endod J 2003; 36:302-307.

21. Maniglia-Ferreira C, Silva JB Jr., Paula RC, Feitosa JP, Cortez DG, Zaia AA, Souza-Filho FJ. Brazilian gutta-percha points. Part I: chemical composition and X-ray diffraction analysis. Braz Oral Res 2005;19:193197.

22. Marciano J, Michailesco PM. Dental gutta-percha: chemical composition, X-ray identification, enthalpic studies, and clinical implications. J Endod 1989;15:149-153.

23. Tanomaru JM, Cezare L, Gonçalves M, Tanomaru Filho M. Evaluation of the radiopacity of root canal sealers by digitization of radiographic images. J Appl Oral Sci 2004;12:355-357.

24. Wu MK, Özok AR, Wesselink PR. Sealer distribution in root canals obturated by three techniques. Int Endod J 2000;33:340-345.

25. Gorduysus $M, A v c u$ N. Evaluation of the radiopacity of different root canal sealers. Oral Surg Oral Med Oral Pathol Oral Radiol Endod 2009; 108:135-140.
Received September 5, 2016 Accepted July 25, 2017 